\title{
JURIANAI
}

Jurnal Pendidikan Ekonomi

$\therefore$ JUR KAIMI

VOLLME

5
NOMOR

2

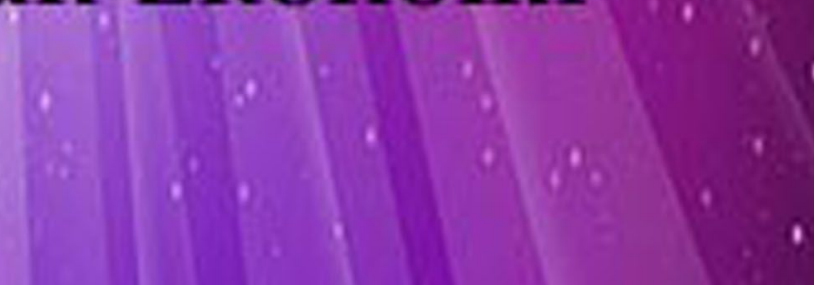




\title{
JURKAMI:Jurnal Pendidikan Ekonomi \\ http://jurnal.stkippersada.ac.id/jurnal/index.php/JPE \\ JURKAMI Volume 5, no 2, 2020
}

\section{PERAN KOPERASI DALAM MENINGKATKAN KESEJAHTERAAN ANGGOTA DI KOPERASI UNIT DESA BALE YOTRO DESA BELOYANG}

\begin{abstract}
Tri Handayani ${ }^{1}$, Avelius Dominggus Sore ${ }^{2}$, Yunita Astikawati ${ }^{3}$
STKIP Persada Khatulistiwa Sintang, Indonesia ${ }^{123}$

Email: trihandayani413@gmail.com ${ }^{1}$, avelius12@gmail.com², yunitaakun@gmail.com ${ }^{3}$

Diterima: 23Oktober 2020; Disetujui: 29 Oktober 2020; Diterbitkan: 1 November 2020

Abstract:This research is against the backdrop of no change in the welfare of cooperative members of bale yotro village unit beloyang village. The aim of this research is explaining the factors that influence the cooperative in increasing the prosperity of bale yotro village cooperative unit's member, beloyang village. Research uses qualitative methods with data collection techniques namely observation, interview and documentation. The results of this research: 1) cooperative plays a major role in enhancing theprosperityofcooperative members, 2) the efforts of cooperatives in increasing the prosperity of their members by developing cooperativebusiness units, providing the needs are needed by members, establishing relationships and cooperation with cooperative partners to achieve the goals of cooperative work programs, and making innovations and opportunities for cooperative members, 3) driving factors and inhibition in improving the welfare of members.
\end{abstract}

\section{Keywords: The Role Of Cooperative, Member'sprosperity}

Abstrak: Riset ini dilatarbelakangi tidak adanya perubahan kesejahteraan anggota koperasi unit desa bale yotro desa beloyang. Penelitian ini bertujuan untuk mendeskripsikan faktor pendorong dan penghambat koperasi dalam meningkatkan kesejahteraan anggota di koperasi unit desa bale yotro desa beloyang. Penelitian menggunakan metode kualitatif dengan teknik pengumpulan data yaitu observasi,wawancara dan dokumentasi. Hasil penelitian: 1) koperasi sudah berperan besar dalam meningkatkan kesejahteraan anggota. 2) upaya koperasi dalam meningkatkan kesejahteraan anggota adalah mengembangkan unit usaha yang dimilki koperasi dengan menyediakan kebutuhan yang dibutuhkan oleh anggota, menjalin relasi dan kerjasama dengan mitra kerja yang mendukung program kerja koperasi untuk mencapai tujuan, dan melakukan inovasi serta membaca peluang untuk meningkatkan kesejahteraan anggota.3) faktor pendorong dan penghambat dalam meningkatkan kesejahteraan anggota.

\section{Kata Kunci: Peran Koperasi, Kesejahteraan Anggota}




\section{PENDAHULUAN}

Badan Usaha Milik Negara, Badan Usaha Milik Swasta dan Koperasi merupakan unsur dalam perekonomian. Koperasi sendiri memiliki peran yang besar terutama di masyakarat kelas menengah kebawah untuk meningkatkan taraf hidupnya.Begitu pula dengan Koperasi Unit Desa Bale Yotro didirikan untuk meningkatkan kesejahteraan anggota.Jenis koperasi ini adalah koperasi unit desa yang menyediaan bahan pokok bagi masyarakat.Namun permasalahnnya adalah sejak pendirian tahun 1994 hingga saat ini koperasi ini masih stagnan dan tidak ada perkembangan.Target koperasi ini nampaknya belum tercapai secara optimal terutama dalam meningkatkan kesejahteraan anggotanya.

Terdapat beberapa kendala pula ang dihadapi oleh koperasi ini selama beroperasi.Pertama koperasi belum mampu memenuhi kebutuhan dan permintaan anggota koperasi untuk pengadaan barang konsumsi. Kedua, koperasi juga menyediaan pupuk untuk anggota tetapi kembali kekurangan setiap tahunnya. Ketiga proses bisnis yang tidak maksimal ini tentunya berdampak pada keuntungan koperasi dan hasil akhir berpengaruh terhadap hasil bagi hasil. Hal ini senada dengan pendapat Mubarok (2018), menyimpulkan bahwa kurangnya pengembangan bisnis dari koperasi menyebabkan keuntungan yang tidak maksimal, kurangnya pengetahuan dan keterampilan dalam mengelola koperasi menyebabkan perencanaan keuangan diawal tidak sesuai dengan pelaksanaan. Selama berdirinya koperasi ini dapat dikatakan bahwa koperasi belum mampu mengoptimalkan kesejahteraan anggota.

Perlu diketahui bahwa kejahteraan anggota tidak hanya diukur dari pendapatan saja namun juga bentuk lainnya. Ikbaludin (2019:119) "Kesejahteraan juga dapat diukur dari kemandirian masyarakat dalam memenuhi kebutuhannya baik materil maupun spiritual". Kemadirian masyarakat nanti diharapkan dapat meningkatkan kemampuan masyarakat.Kemampuan masyarakat meningkat apabila masyarakat mendapatkan pendampingan dan pemberdayaan.

Bentuk pemberdayaan yang dilakukan dengan cara menumbuhkan kesadaran dan memberikan pelatihan agar masyarakat mempunyai keterampilan untuk mengolah potensi yang mereka miliki dan bisa mengatasi permasalah yang mereka hadapi (Harahap, 2017). Oleh karena itu maka perlu dianalisis lebih lanjut untuk menemukan solusi untuk mengatasi permasalahan ini. Adapun yang akan dianalisis yaitu berkaitan dengan peran, upaya, faktor pendorong dan penghambat koperasi dalam meningkatkan 
kesejahteraan anggota di Koperasi Unit

Desa Bale Yotro Desa Beloyang.

\section{KAJIAN TEORI}

Koperasi sudah tidak asing lagi terutama di masyarakat Indonesia.Koperasi telah tumbuh dan berkembang bersamaan dengan perkembangan ekonomi masyakarat.koperasi adalah suatu organisasi yang anggotanya memiliki tujuan yang sama dengan cara bekerja sama dalam mencapai tujuan yang telah di tetapkan. Koperasi terdiri dari pengurus dan anggota. Pengurus dan anggota bekerja sama dalam rangka mewujudkan kesejahteraan anggota dan masyarakat serta membangun tatanan perekonomian nasional.Koperasi memiliki landasan kerja sama yang didasarkan pada kesetaraan hak dan kewajiban yang dikukuhkan dalam rapat anggota. Berdasarakan jenisnya koperasi dapat dibedakan dari kegiatan operasinya. Koperasi yang umunya dibangun untuk meningkatkan kondisi ekonomi perdesaaan adalah koperasi unit desa atau yang sering kita sebut dengan KUD.Koperasi Unit Desa merupakan badan usaha yang berasal dari masyarakat yang bertujuan membantuusaha-usaha masyarakat mendapatkan kemakmuran yang adil beradab.

Sumber permodalan untuk koperasi ini berasal modal sendiri dan modal pinjaman. Modal sendiri berasal dari :simpanan pokok, simpanan wajib, dana cadangan dan hibah. Modal pinjaman berasal dari Anggota, Koperasi lain atau anggotanya, Bank dan lembaga keuangan lainnya, Penerbitan obligasi dan surat utang lainnya dan Sumber lain yang sah. Modal koperasi merupakan unsur yang menjadi salah satu kunci kesuksesan koperasi.

Burhanuddin(2018)menyimpulkan bahwa modal sendiri dan modal pinjaman berpengaruh terhadap rentabilitas ekonomi pada Koperasi. Modal dan usaha yang dilakukan oleh KUD tentunya bermuara kekesejahteraan anggota.Kesejahteraan anggota yang merupakan bagian dari masyarakat tidak hanya dilihat dari pendapatan saja. Menurut Badan Pusat Statistik (2019) mengatakan bahwa :Indikator yang digunakan untuk mengetahui tingkat kesejahteraan yaitu Kependudukan, Kesehatan dan Gizi, Pendidikan, Ketenagakerjaan, Taraf dan Pola Konsumsi, Perumahan dan Lingkungan, Kemiskinan, serta Sosial Lainnya yang menjadi acuan dalam upaya peningkatan kualitas hidup.Menurut Ikbaludin (2019) indikator kesejahteraan yang dimaksud dalam kesejahteraan anggota adalah sebagai berikut :

1. Tingkat pendapatan keluarga 
2. Komposisi pengeluaran rumah tangga dengan membandingkan pengeluaran untuk pangan dengan non-pangan,

3. Tingkat pendidikan keluarga

4. Tingkat kesehatan keluarga

5. Kondisi perumahan serta fasilitas yang dimiliki dalam rumah tangga

Kesejahteraan anggota akan tercapai apabila koperasi tidak hanya membantu menyediakan kebutuhan anggota tetapi lebih daripada itu. Koperasi harus dapat memberikan pendampingan baik dari segi moral maupun aspke non moral.Selain pendampingan, koperasi juga harus dikelola dengan baik.Apabila koperasi tidak dikelola dengan baik tidak hanya berdampak terhadap sisa hasil usaha saja tetapi timbulnya ketidakpercayaan anggota. Hal ini menyebabkan anggota akan mundur dari waktu ke waktu. Aktivitas mundurnya anggota ini menunjukan bahwa loyalitas anggota semakin menurun akibat dari pengelolaan yang kurang baik.

Hal ini senada dengan yang diungkapan oleh Finanto dan Iswanto (2020)yang menyatakanloyalitas anggota menurun akibat dari pengurus koperasi yang tidak melaksanakan good cooperative governance dan tidak melakukan tata kelola keuangandengan baik dan akuntabel.Apabila koperasi sudah dianggap mampu memberikan pendampingan dan pengelolaan yang baik harapannya koperasi sudah menjalankan perannya secara baik. Peran dari koperasi sendiri menurut Undang-Undang No 25 Tahun 1992 Bab 3 pasal 4 tentang Perkoperasian menyatakan bahwa :

1. Membangun dan mengembangkan potensi dan kemampuan ekonomi anggota pada khususnya dan pada masyarakat pada umumnya untuk meningkatkan kesejahteraan ekonomi dan sosialnya.

2. Berperan serta secara aktif dalam upaya mempertinggi kualitas kehidupan manusia dan masyarakat.

3. Memperkokoh perekonomian rakyat sebagai dasar kekuatan dan ketahanan perkonomian nasional dengan koperasi sebagai sokogurunya.

4. Berusaha mewujudkan dan mengembangkan perekonomian nasional yang merupakan usaha bersama berdasarkan atas asas kekeluargaan dan demokrasi pancasila.

Peran koperasi yang baik ini tentunya lebih baik jika dapat diimplementasikan secara maksimal.Sehingga koperasi dapat memberikan kontribusi positif bagi masyarakat. Terutama menambah pengetahuan dibidang kewirausahaan yang dapat berguna dalam kehidupan sehari-hari ( Sandri, 2016) 


\section{METODOLOGI PENELITIAN}

Riset ini menggunakan metode penelitian kualitatif deskriptif .riset ini berbentuk studi kasus. Riset akan dilakukan di Koperasi Unit Desa Bale Yotro desa yang beralamat di Desa Beloyang. Riset akan dilakukan untuk memperoleh data primer dan data sekunder yang berkaitan dengan peran KUD dan kesejahteraan anggota. Data primer dan data sekunder akan diperoleh menggunakan teknik pengumpul data berupa observasi, wawancara dan dokumentasi.

Teknik analisis data yang digunakan Peneliti adalah teknik analisis model Miles and Hubermen yang mencakup data collection, data reduction, data display, dan Conclussion Drawing/verification. Data yang diperoleh nantinya akan diuji kembali untuk menentukan keabsahan data. Adapun uji yang dilakukan mencakup uji credibility (validityas interbal),transferabilyty(validitas eksternal),dependabilyty(realibilitas) dan konfirmability (obyektivitas)

\section{HASIL DAN PEMBAHASAN}

\author{
Koperasi Unit Desa Bale Yotro \\ didirikan tahun 1994 oleh Drs. Jafar
}

Kurniadi, Drs. Marsel, Drs. Rubai, Fauzan, dan Sebron.Jumlah anggota pertama yaitu 500 anggota jadi modal awal yang dimiliki koperasi yaitu $\mathrm{Rp}$ 2.500.000.Kegiatan koperasi saat itu hanya mengurus pembagian jatah hidup (Jadup) dari pemerintah untuk dibagikan kepada masyarakat daerah transmigrasi. Tahun 1994 hingga 2004 koperasi ini membangun unit usaha saprodi (pupuk dan racun), unit usaha waserda dan unit simpan pinjam serta menjalin kerja sama dengan perusahaan bumi putera dengan mengikuti program asuransi jiwa serta melakukan persiapan peremajaan kebun sawit.

Tahun 2004 Koperasi Unit Desa Bale Yotro menambah satu unit usaha yaitu sarana angkutan dan menutup satu unit usaha yaitu penyediaan pupuk karena beberapa hal yang tidak memadai. Koperasi ini telah berkerjasana dengan berbagai pihak guna melancarkan kegiatan koperasi dalam memenuhi kebutuhan anggota.Pihak tersebut mayoritas merupakan pihak swasta.Dari pihak pemerintah sendiri belum ada yang menyambangi KUD Bale Yotro guna membuat kerjasama. Adapun pihaksawasta yang berkerjasama dengan koperasi adalah sebagai berikut 
Tabel 1: Mitra Kerjsama Koperasi Unit Desa Bale Yotro

\begin{tabular}{|c|c|c|}
\hline Nama mitra & Bidang kerja sama & Tempat \\
\hline Perseroan Terbatas Sinar Dinamika Kapuas 1 & $\begin{array}{l}\text { Penjualan } \\
\text { tandan buah sawit }\end{array}$ & Batu buil \\
\hline $\begin{array}{l}\text { Bank BNI,bank BRI,bank mandiri, bank Mandiri } \\
\text { Syariah, PNM, BPDPKS, }\end{array}$ & Permodalan & $\begin{array}{l}\text { Nanga Pinoh } \\
\text { dan Sintang }\end{array}$ \\
\hline Toko Sahabat Tani,makmur tani & $\begin{array}{l}\text { Pupuk dan } \\
\text { racun sawit }\end{array}$ & Nanga Pinoh \\
\hline $\begin{array}{l}\text { Toko Putra jaya,toko sinar terang,toko melati, toko } \\
\text { melawi elektornik }\end{array}$ & Sembako & Nanga Pinoh \\
\hline Toko SahabatKramik,toko jasa material,toko lestari & Bangunan & Nanga Pinoh \\
\hline Toko Luky & Alat tulis kantor & Nanga Pinoh \\
\hline Persekutuan Komanditer Balaban Mekar & Peremajaan sawit & Sekadau \\
\hline
\end{tabular}

Sumber: Data Koperasi Unit Desa Bale Yotro 2020

Koperasi yang telah berdiri lama dan memiki mitra tentunya tidak sertamerta memiliki performa yang baik.Koperasi juga membutuhkan gebrakan baru untuk mempertahankan kosnistensinya dalam membantu masyarakat.Konsistensinyalah yang menjadi hal yang sulit dilakukan karena konsisten bukan berarti tidak berinovasi namun sebaliknya.Tentu hal ini menjadi titik berat bagi KUD Bale Yotro agar terus dapat eksis berperan aktif dalam membantu anggotanya dari segi ekonomi.

Oeh karena itu perlu dilakukan analisis lebih mendalam mengenai perkembangan KUD Bale Yotro. Riset ini dilakukan dengan beberapa alat pengumpul data yaitu lembar wawancara, lembar observasi dan dokumentasi.
Subjek riset terdiri dari 10 anggota KUD Bale Yotro. Riset dilakukan mulai bulan maret hingga agustus tahun 2020. Berdasarkan hasil data dan analisis data diperoleh infromasi yang digambarkan dalam beberapa hal. Pertama, Koperasi Unit Desa Bale Yotro Desa Beloyang mengembangkan usaha untuk mencapai tujuan dengan berdasarkanetos kerja didasarakan atas asas, kejujuran, kedisiplinan,komitmen dan tata kelola yang baik. Pengelolaan keuangan yang telah dilakukan dengan baik pula karena KUD Bale Yotro telah membuka seluasluasnya bagi anggota untuk meilhat laporan keuangan koperasi. Hal ini dilakukan agar asas transparansi dalam pengelolaan uang anggota tetap terjaga. Apabila pengelolaan keuangan telah 
tranparans maka kepercayaan anggotapun akan terpelihara. Kedua, pelatihan dan penyuluhan yang diikuti oleh pengurus dan karyawan koperasi. Penyuluhan dan pelatihan dilakukan oleh Asosiasi Petani Kelapa Sawit Indonesia (APKASINDO), Badan Pertegasan Komitmen Dukungan Sawit Berkelanjutan atau BPDPKS dan Bank Rakyat Indonesia Life. Namun pelatihan dan penyuluhan tidak dilakukan setiap tahunnya dan yang hanya untuk pengurus dan karyawan saja.Anggota tidak pernah diberikan pelatihan dan penyuluhan dari pihak manapun.Padahal Catur dan Setiawina (2018) Koperasi perlu meningkatkan pengetahuan anggota tentang koperasi dengan menyelenggarakan pelatihan tentang perkoperasian.Hal ini patutlah menjadi refleksi bagi koperasi bahwa kesejahtreraan anggota itu tidak dapat diukur melalui uang saja, perlu tambahan pengetahuan yang baik untuk anggotanya. Perlu diingat bahwa sejahtera tidak hanya dilihat dari pengutan keuangan saja tanpa pola pikir yang baik. Sebaliknya jika pola pikir anggota baik dan luas maka tidak ada kata tidak bagi anggota untuk meningkatkan kesejahteraanya. Kesejahteraan anggota seyogyanya terlihat dari pola pikir anggota yang berubah. Contoh saja anggota koperasi yang awalnya tidak dapat mengeposkan pengeluaran akibat dari pelatihan dari koperasi, anggota dapat mengeposkan pengeluaran secara baik. Tentu saja hal sederhana ini mampu memberikan efek besar bagi anggota. Namun hal sederhana ini saja belum pernah dilakukan oleh koperasi. Koperasi harusnya memfasilitasi anggota untuk mendapatkan wawasan lebih luas karena tidak semua anggota koperasi memiliki tingkat pendidikan tinggi. Mayoritas hanya lulusan sekolah dasar hingga menegah atas. Hal ini menjadi pekerjaan rumah tersendiri bagi koperasi. pelatihan dan penyuluhan tidak melulu berasal dari luar, tetapi bagaimana koperasi membangun diri dari dirinya sendiri.

Ketiga, koperasi melayani anggota dengan asas kekeluargaan sesuai dengan prinsip dasar koperasi. Hal ini terlihat dari aktivitas operasional dan nonoperasinal yang berlaku di KUD Bale Yotro. KUD Bale Yotro secara rutin melakukan pertemuan dengan anggota untuk membahas permasalahan koperasi. Tidak hanya permasalahan berkaitan dana saja, koperasi juga melibatkan anggota dalam penentuan program kerja tahunan. Koperasi juga menjaring pendapatan anggota dalam penentuan karyawan yang bekerja di dalam koperasi. Setiap kedudukan dan struktur koperasi didasarkan pada hasil musyawarah dengan anggota. Hal ini dilakukan bahwa koperasi sadar betul bahwa kemajuan 
koperasi tidak akan lebih dari kemajuan anggota dan partisipasi anggota. Oleh karena itu koperasi berusaha melibatkan anggota dalam segala usaha. Keempat, koperasi menyediakan dana pinjaman kepada anggota yang ingin membuka usaha secara mandiri. KUD Bale Yotro memberikan kemudahan bagi anggota yang akan membuka usaha atau memperluas usahanya. Hal ini terlihat dari 659 anggota saat ini terdapat 264 anggota atau $40 \%$ anggota telah memiliki usaha mandiri yang dananya diperoleh dari koperasi. Adapun usaha mandiri yang dimiliki anggota koperasi adalah perkebunan karet,warung sembako, pembuatan tahu,pembuatan tempe,jualan sayur mayur, perikanan, ternak ayam potong, peternak telur ayam atau ayam boiler,depot air galon,bengkel motor, sarang walet, tengkulak karet, penjahit baju, konter pulsa, token listrik dan usaha kecil lainnya seperti bakso keliling,somai dan cendol. Angka 40\% tampak besar namun dari $40 \%$ tersebut tidak semua bejalan dnegan mulus. Koperasi tetap harus meningkatkan jumlah pengguna jasa koperasi menjadi lebih tinggi terutama dengan meminjamkan ke sektor rumah tangga. Industri rumah tangga akan bangkit jika koperasi memberikan pendampingan tidak hanya berupa pendanaan saja namun pelatihan pula. Pelu dingat bahwa jika dana berlimpah namun anggota tidak memiliki skill yang memadai maka dana akan mengangur saja. Bahkan dana hanya dipijamkan dalam bentuk pinjaman konsumtif yang tidak membangun. Perlu ditekankan bahwa industri rumah tangga memiliki peran besar bagi anggota untuk meningkatkan perekonomiannya.

Kelima, KUD bale Yotro belum dapat membantu secara maksimal meningkatkan perekonomian anggota. Koperasi hanya mampu memberikan kredit kepada anggota dalam jumlah yang masih terbatas.Selain itu, masih banyak dari anggota koperasi yang tidak memanfaatkan secara baik kredit yang diberikan oleh koperasi.Mayoritas anggota koperasi masih meminjam uang ke koperasi untuk memenuhi kebutuhannya yang bersifat konsumtif. Saat kekurangan penhasilan anggota akan meminjam dana ke koperasi dan akan di angsur secara berkala jika anggota mendapatkan upah bulanan. Hal ini serupa seperti gali lobang tutup lobang. Sebaiknya koperasi dapat memberikan edukasi bagi anggota untuk lebih memprioritaskan pinjaman produktif mapun edukasi berkaitan dengan pengelolaan dana kredit. Proses edukasi disini lebih ditujukan untuk memberikan mutu pelayanan yang baik kepada nasabah agar kegiatan pemberian pinjaman modal dan 
pengambilan angsuran berjalan dengan baik (Sianipar, 2019).

Keenam, koperasi membantu dana pendidikan anak anggota berupa beasiswa. Koperasi juga menyediakan alat tulis kantor dan fotokopi milik koperasi untuk digunakan oleh anak-anak yang tidak mampu. Selain itu KUD bale Yotro juga setiap tahunnya menyisihkan $5 \%$ dari Sisa hasil usahanya untuk membantu guru yang masih honorer di desa Beloyang dari tingkat Taman kanak-kanak hingga tingkat Sekolah menegah keatas.

Ketujuh, koperasi tidak membantu anggota dalam memenuhi kebutuhan yangh bersipat pangan tetapi yang bersifat papan diberikan bantuan. Bentuan ini berupa menyisihkan dana 5\% dari sisa hasil usaha untuk membantu masyarakat baik anggota maupun bukan anggota koperasi untuk mendiami rumah yang layak.

Secara garis besar keberadaan KUD Bale Yotro telah membantu masyarakat memperbaiki taraf hidupnya menjadi lebih baik. Namun tentu saja dalam proses memperbaiki taraf hidup masyarakat terdapat beberapa faktor yang menunjang dan menghambatnya. Berikut adalah faktor-faktor tersebut:Faktor pendorong koperasi dalam meningkatkan kesejahteraan anggota adalah
1. Ketersediaan modal yang cukup untuk mengembangkan unit usaha yang dibutuhkan anggota.

2. Kemampuan manajerial untuk mengelola koperasi dengan baik yang melibatkan berbagai unsur yang ada dalam koperasi seperti pengurus,pengawas, anggota serta mitra kerja koperasi.

3. Partisipasi anggota yaitu dengan antusiasnya anggota koperasi menggunakan unit usaha koperasi yang menjadikan pengurus koperasi untuk melakukan dan menghasilkan kinerja yang baik.

Faktor penghambat koperasi dalam meningkatkan kesejahteraan anggota adalah

1. Kecemburuansosial diantara anggota terlebih pada anggota yang memiliki ilmu dan pendapatan yang tinggi.

2. Ketidakselarasan antara pengurus dan anggota yang disebabkan kurang terbukanya pengurus koperasi dan anggota mengenai program kerja yang tidak jelas sehingga mengakibatkan program kerja tersebut tidak berjalan dengan baik.

Pihak luar yang merasa tersaingi sehingga mempengaruhi anggota yang kurang mendukung koperasi atau kurang berpartisipasi terhadap koperasi 


\section{PENUTUP}

Hasil analisis dalam riset ini dapat disimpulkan bahwa Koperasi Unit Desa Bale Yotro sudah berperan besar dalam meningkatkan kesejahteraan anggota. Cara yang ditempuh oleh koperasi melalui mengembangkan unit usaha dan kerjasama dengan pihak lain. Walaupun koperasi sudah berjalan dengan baik tetapi prinsip dari good governance belum cara benar. Hal ini terlihat belum adanya keterbukaan program kerja koperasi, program kerja yang tidak sesuai dengan realisasinya dan lack dari pengurus koperasi.Oleh karena itu sebaiknya semua program kerja dapat dibahas dan diputuskan secara bersama dalam rapat anggota berserta pengurus.Perlu adanya peningkatan kapasitas dan kapabilitas dari anggota dan pengurus koperasi dan dilakukan secara berkala.

\section{DAFTAR PUSTAKA}

Burhanuddin. 2018. Pengaruh Modal Sendiri Dan Modal Pinjaman Terhadap Rentabilitas Ekonomi Pada Koperasi Simpan Pinjam Karya Bersama Palu. Jurnal Sinar Manajemen.5(2): 92-97.

Catur I Ketut Dan Nyoman Djinar Setiawina. 2018. Faktor-Faktor Yang Mempengaruhi Partisipasi Anggota Koperasi Dan Kesejahteraan Anggota Pada Koperasi Unit Desa (Kud) Di Kabupaten Jembrana. EJurnal Ekonomi Dan Bisnis Universitas Udayana. 7(2): 25092534.
Finanto Hasto Dan Iswanto Totok. 2020. Analisis Identifikasi Permasalahan Koperasi Politeknik Balikpapan Dalam Upaya Meningkatkan Kesejahteraan Anggota.Akuntabel. 17(1): 253-260.

Harahap Friska Indria Nora. 2017. Pemberdayaan Masyarakat Pemulung Sampah Sungai Citarum Melalui Koperasi Bangkit Bersama.Jurnal Pendidikan dan Pemberdayaan Masyarakat.4(1):180-186.

Https://www.bps.go.id/publication/2020/6/ 7/27d78d49bc6aa22bd3672b59/indik ator-kesejahteraan-rakyat2019.htmldiakses pada 7 juni 2020

Ikbaludin.2019. Peran Koperasi UIKA (KIKA) dalam Mensejahterakan Anggota (Studi Kasus pada Koperasi KIKA Universitas IBN Khaldun Bogor).Jurnal Ekonomi Keuangan Syariah.Vol 3 No. 1 January 2019 Page 115-129.

Mubarok Nurul. 2018. Analisis Identifikasi Masalah Utama Koperasi Di Kabupaten Banyuasin Dalam Mewujudkan Kesejahteraan Anggota. I-Economic: a research journal on islam economics. 4 (2):194-213

Sianipar Agustina Mariana. 2019. Peranan Koperasi Gapoktan Terhadap Upaya Pemberdayaan Ekonomi Masyarakat Di Desa Huta Nauli. Journal Of Management Science. 2(3): 61-67.

Sandri siti hanifa. 2016. Keefektifan Peranan Koperasi Guna Meningkatkan Kesejahteraan Anggota Dan Masyarakat Daerah Marsawa, Kecamatan Sentajo Raya, Kabupaten Kuantan Singingi (Studi Kasus Kud Langgeng).Jurnal 
112 | Tri Handayani, Avelius Dominggus Sore, Yunita Astikawati,Peran Koperasi Dalam

Ekonomi Dan Bisnis Darma Andalas.

18(2): 362-370.

Undang-Undang RI Nomor 25 tahun 1992

tentang Perkoperasian diterbitkn

oleh Sinar Grafika 